\title{
Evaluation of Tourism Development Situation in the Russian Federation in 2000-2015: The Case of Kaliningrad Region
}

\author{
Elena G. Kropinova \\ Immanuel Kant Baltic Federal University, Russian Federation \\ Corresponding Email: ekropinova@kantiana.ru
}

\author{
Doi:10.5901/mjss.2015.v6n6s7p165
}

\begin{abstract}
The tourist industry in different regions of the Russian Federation changed significantly in 2000-2015. All these changes are typical of the Kaliningrad region as one of its most profitable tourism directions, an inbound international one, started developing only in the middle of the 1990-s. This research is aimed at studying shifts in the region's tourism industry in the frameworks of its major sectors: accommodation sector, intermediary services' sector (tourist companies) and HoReCa sector. The research results reflecting the dynamics of these tourism components are presented in tables and diagrams. The region has not reached the Soviet-period level of health resort tourism yet; peak of foreign tourists number was in the end of 1990-sbeginning of 2000-s. The biggest number of Russian tourists was observed in 2014. Analyses of impacting factors is provided along with elaborated recommendations.
\end{abstract}

Keywords: tourism, Kaliningrad region, recreational system, tourist companies, accommodation sector, regional development

\section{Previous Studies of Tourism Industry in the Kaliningrad Region}

A significant number of papers is devoted to development of tourism in the Kaliningrad region of the Russian Federation. Some researchers specialize in particular spheres of tourism. For instance, Dragileva (2006) focused on touristrecreational resources of the territory. Development of bordering regions was studied by Korneevets and Kropinova (Korneevets, 2010; Kropinova, 2010, 2014; Korneevets \& Kropinova, 2014). Issues of tourist cluster were addressed by Kropinova \& Mitrofanova (2011); modeling of "Recreation and tourism" sphere was scrutinized by E.G. Kropinova, N.A. Zaytseva, and M. Moroz (2015). It should not come as a surprise that the majority of the specialists come from the Kaliningrad region.

However, the works of non-local experts in this field are appealing as well, as most of them focus on comparative analyses of the Kaliningrad region and other Russian regions (e.g. regions also located in the Northwestern Federal District) (Fedorova, 2015; Derendyaeva \& Muhina, 2013) or even comparative analyses of the region and the bordering states which have similar potential and positive experience of its development (Spiriajevas, 2013).

The majority of the publications are attributed to the attempts determine main trends of the industry development. For example, an article "Formulation of development strategy for tourism and recreational system in the Kaliningrad region" by Aidarov and Lavrov (2014) is, in fact, a transformed version of program documents elaborated by the government of the Kaliningrad region. Although the value of the assessment of the regional potential and comparative analyses of the Northwestern regions of Russia given in it is undeniable. Analyses made in the framework of the government contracts or by a group of academics are of greater importance for the trend development forecasts. Case in point is a research report called "Formulation of framework for integrated tourism development in the Kaliningrad region for 2012-2018/2022, including measures for infrastructure development (restoration, building), the list of existing assets (or assets under reconstruction) with reference to specific tourist zones of the Kaliningrad region" (Report, 2012). Its results provided the basis for the "Tourism" government program in the Kaliningrad region and enabled the region to join Federal Target Program (FTP) "Development of domestic and international tourism in the RF in 2011-2015" ("Tourism" program, 2013).

Therefore, the relevance of the article is determined by its analyses of the tourism development dynamics in 20002015 based on the official statistical data, on the author's expert assessment of the tourism industry in the given period and the author's vast experience in elaboration of program documents and development strategies. 


\section{General Characteristic of the Tourism Sector in the Kaliningrad Region}

The resource potential for the development of recreational and tourism sectors in the Kaliningrad region is above the average comparing to the other regions of Russia. According to Fedorova's (2015) point rating of the principal resources, i.e. accommodation facilities per 1000 square kilometer, the Kaliningrad ranked first having scored 72 points (to put this in perspective, in the Northwestern Federal District it is followed by the Leningrad region with only 50 points). In the distribution of cultural sites and architectural attractions the region scored 156 points, the same number as the Novgorod and Pskov regions (famous Russian historical centers). The number of points the region gained for the quantity of specially protected natural areas is comparable to that scored by the Republic of Karelia which is Russian leader in nature tourism (54 and 48 points respectively) (Fedorova, 2014). This makes the region a territory with high potential for tourism development. In terms of its nature and heritage the Kaliningrad region is highly competitive with the neighboring areas of the Southeastern Baltic coast (The Tricity in Poland; Neringa and Palanga in Lithuania). Although neither the volume nor the quality of the provided tourism services corresponds in full to the existing potential. Moreover, in 20002015 there were crucial changes in the tourism industry primarily associated with the tourism infrastructure development that provided twofold increase in tourist arrivals. Yet, the current occupancy rate (particularly, in health resorts) is still below that of the Soviet period. Indeed, virtually till the end of 1980-s the number of tourists arriving into the Kaliningrad region amounted for up to 800000 people a year. This is attributed to the administrative-command system. The distributive method of centralized management provided for the balanced occupation of the USSR's resorts in terms of both geography and seasons. Besides, the "the region's detachment" from mainland Russia was not a constraint back then. Furthermore, alternative resorts outside the USSR were not available to the majority of Soviet citizens.

\section{Quantitative and Qualitative Changes in Tourist Flows Patterns in 2000-2014}

The number of tourists arriving in the region has doubled since 2000 (see Fig.1). In 2013, the number of tourists (people entering the region for tourism) was 475 thousand people; the number of border crossings (gross number of visitors to the region) was 2.5 million people (Report, 2014).

The majority of the tourists is still Russians. Moreover, their share has been on the rise in recent years. It has increased from $77 \%$ in 2002 to $86 \%$ in 2012. According to experts' estimations in 2014 over 90\% of tourists came from Russia. This is due to both the imposed sanctions and the growth of the interest in the region. Russia's fascination for the Kaliningrad region arises not only from the fact that it is the Westernmost part of the RF but also from the fact that after the demise of the USSR the country lost a lot of the Baltic sea resorts (Yurmala, Palanga, Pyarna etc.). As the standards of living rise and the regional tourist system develops, the tourist flow from Russian regions grows. In this context, it is important to increase and maintain the flow of tourists.

International tourism started developing after 1990 when the region was opened to foreign visitors. Over 60 thousand tourists come to the region annually mainly from Germany, Poland, Lithuania, Belorussia and Nordic countries (Fig. 2). The peak of international tourism was in the end of 1990-s -beginning of 2000-s (up to 64 thousand people).

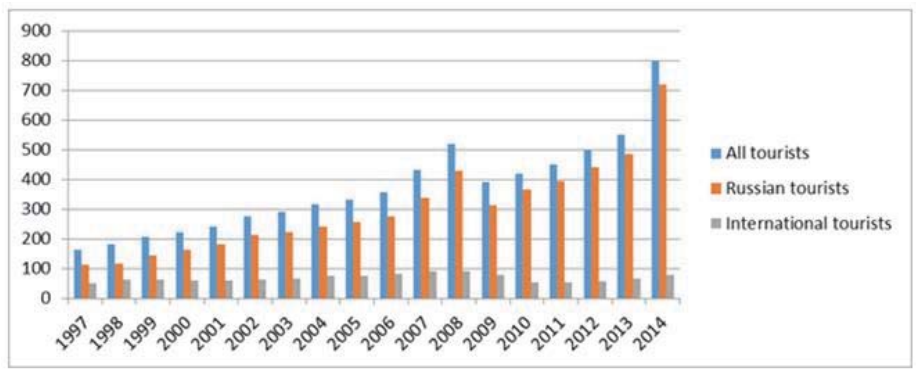

Figure 1. Dynamics of inbound tourism in the Kaliningrad region, 1997-2014 (Report, 2015) 

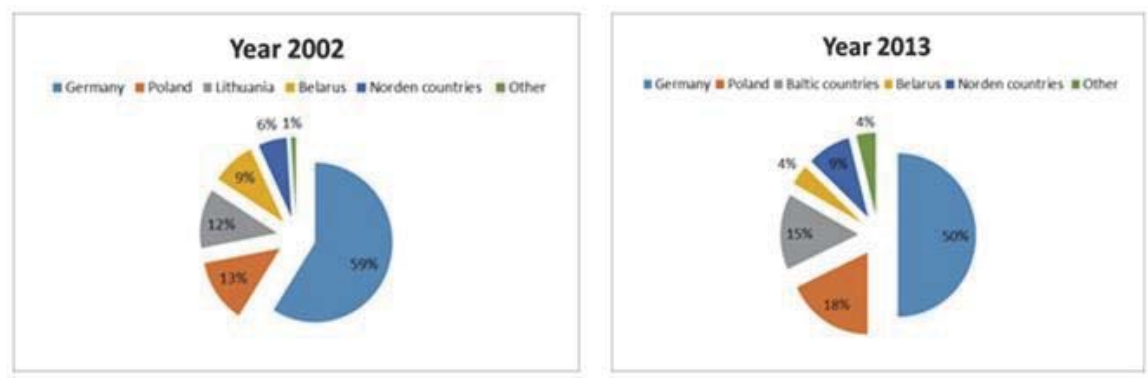

Figure 2. Structure of inbound tourism in the Kaliningrad region by countries, percentage of the total number Source: Official web site of the Ministry of Tourism of the Kaliningrad region.

In 2002, while making an assessment of tourism development opportunities and incidental increase in employment in this and related industries, experts assumed that the share of labor force directly or indirectly occupied in recreation and entertainment industry could increase to $10 \%$, and the share of this system in the gross regional product (GRP) could grow up to $5-8 \%$.

However, in 2012, 9.6 thousand people worked in HoReCa sector that accounted for only $2 \%$ of all labor force in the region (which is equivalent to the rate of $2012-2 \%$ (Regions of Russia, 2002). In 2013, the budget revenue from tourism product sale (net of VAT, excises and similar obligatory payments) was 749948.6 thousand rubles, this amounts for $125 \%$ of the 2012 revenue.

The share of hotels and restaurants in the GRP was 1.4\% in 2005 and $0.9 \%$ in 2012 (this percent is lower than national average amounting for $1 \%$ of a GRP).

\section{Accommodation Facilities}

The distribution of companies providing tourist services is highly uneven throughout the region. Such a distribution was developed during Soviet period when the major attraction for tourists coming from all over the USSR was the seaside, and the main type of recreation was swimming and bathing as well as health resort retreat. Thus, the overwhelming majority of tourist companies (90\%) is located along the coast. The situation changed once the region was opened to overseas visitors. Heritage sites became another important attraction for tourists and even the major attraction for tourists from abroad. That provided for the tourism infrastructure development in other areas of the region.

At the same time, integration of the Kaliningrad region into tourist trails of the Baltic region and the development of business tourism brought along the increase in demand for comfortable accommodation.

The statistics on collective accommodation facilities in the Kaliningrad region in 2002 and 2013 are provided in the Table 1.

Table 1. Statistics on collective accommodation facilities in the Kaliningrad region in 2002 and 2013

\begin{tabular}{lcc}
\hline Indicator & 2002 & 2013 \\
\hline Number of organizations, units & 78 & 85 \\
Number of rooms, units & 3030 & 5500 \\
Number of people accommodated & 70000 & 272603 \\
\hline
\end{tabular}

Source: On the activity of collective accommodation facilities (2013), On the activity of collective accommodation facilities (2014).

Analyses of the reports of the Kaliningrad region Government shows that hotel occupancy rate from 2000 until today is $30-40 \%$ in a low season (October-April) and $100 \%$ in a high season, an average annual rate is $50-60 \%$. The major changes over the specified period were connected to the modernization of the hotel rooms (leading in some cases to the decrease in room stock) and chain-hotels entrance into the regional market - Radisson (2010) and lbis (2013). 


\section{Catering Companies}

In 2000, in the Kaliningrad region there were 120 bars and restaurants, a large number of various cafes (including seasonal) with over 7300 seats (statistically they serve approximately 846 thousand customers a year).

At the moment there are about 150 bars and restaurants (analyses data on the outcomes of the project conducted in Sept-Oct 2014), cafes (there are over 80 in Kaliningrad only) with about 15 thousand seats. According to the data, they serve approximately one million customers annually.

The catering market is generally attractive and rapidly developing, and according to experts' estimations, it meets the needs of the current tourist flow. However, when the tourist flow increases, the demand for catering companies will also grow, especially in resort zones. For instance, when the tourist flow is $1.5 \mathrm{M}$ people, additional 15 thousand seats will be required (this means 300 more catering companies with an average capacity of 50 seats, i.e. twofold increase, or 150 companies with a capacity of 100 seats).

\section{Tourist Companies}

In 2000, according to state statistics, there were 52 tour operators and 104 travel agents; in 2013, there were 92 tourist companies including 52 travel agents (56.5\%) (Table 2).

Table 2. Data on travel agencies in the Kaliningrad region in 2009-2013 (by type of activity), units

\begin{tabular}{lccccccccccc}
\hline Indicators & 2002 & 2004 & 2005 & 2006 & 2007 & 2008 & 2009 & 2010 & 2011 & 2012 & 2013 \\
\hline Total & 94 & 41 & 38 & 47 & 45 & 67 & 44 & 87 & 81 & 90 & 92 \\
\hline Including travel agents engaged in tour operating & 52 & 21 & 18 & 24 & 21 & 26 & 20 & 34 & 9 & 6 & 4 \\
Engaged in tour operating and travel agents & 52 & 20 & 10 & $\mathrm{n} / \mathrm{a}$ & $\mathrm{n} / \mathrm{a}$ & $\mathrm{n} / \mathrm{a}$ & $\mathrm{n} / \mathrm{a}$ & $\mathrm{n} / \mathrm{a}$ & 33 & 38 & 35 \\
travel agents & 104 & 10 & 10 & 17 & 20 & 37 & 21 & 43 & 37 & 45 & 52 \\
\hline
\end{tabular}

Source: On the activity of tourist companies, 2011; On the activity of tourist companies, 2012; On the activity of tourist companies, 2013.

As Table 2 shows, the total number of tourist companies in the region has doubled over the last 5 years (it increased from 44 to 92 companies), but there were significant changes in the structure by types of activities. In 2009, 20 companies out of 40 were engaged in tour operating (45.4\% of the total number of tourist companies). In 2013 , only four companies engaged in tour operating remained (4.3\% of the total number of tourist companies' number). This is due to the changes in the state regulation system for tourist companies' activities and elaboration of the Uniform register of tour operators by Russian Federal Agency for Tourism (RosTourism) (in accordance with The Federal Law of 28 June, 2009 no. 123-FZ «On amendments to the article 17.2 of the Federal Law «On the principles of Tourist Activity in the Russian Federation») which includes only the companies able to provide financial guarantees in the amount relevant to the sphere of tour operating activities (from 500 thousand rubles to 100 million rubles and more).

\section{Conclusion}

The development of tourism in the Kaliningrad region is based on its high resource potential comparable to that of the Republic of Karelia in terms of nature and in terms of heritage to that of the Pskov and Novgorod regions of the RF.

Analyses of the quantity of tourist arriving in the Kaliningrad region in 2000 and in 2014 showed twofold increase. The main reason for that might be the regional government's policy on preparing tourists attractions for visiting, modernization and increase in the number of hotel facilities, development of catering sector and upgrading the quality of the tourist product ( $\mathrm{HoReCa}$ ) to the European level as well as marketing programs realization.

The percent of Russian tourists in the arrivals in the region has been gradually increasing from 2000 to 2015. The reason for this is the decline in nostalgic tourism, which was on the rise in the region in 1990-s-2000-s. The other reason is positive impact of the implementation of the RF government's policy on the development of domestic tourism.

Regardless of the efforts made to increase the share of tourism in GRP, in 2000-2015 it remained at the rate of $2 \%$. However, in absolute terms there is an increase in the revenue from tourism product sales.

The main changes in accommodation sector are connected with the modernization of the hotel rooms and international chain-hotels (Radisson, Ibis) expansion into the local market. In 2014-2015, measures have been taken to 
improve the service quality in the hotels. This became possible due to the co-funding program for hotels undergoing classification procedure. By June 201528 out of 198 hotels have been classified (Official website of the Ministry of Tourism of the Kaliningrad region, 2015).

Catering market continues its rapid development. Although now there are over 150 bars and restaurants attractive to tourists, their 15 thousand seats will not be enough when the number of tourists increase to the declared 1.5 million people.

The number of tourist companies largely depends on the RF government's policy on the optimization of their performance. By 2015, the number of tour operators has declined, while some of them became travel agents. This is largely connected with the introduction of high payments on bank guarantees, which could be provided only by market majors. However, such high payments are not relevant for the Kaliningrad region located close to Europe. They are aimed at air travel coverage, while bus tours prevail in the region.

Therefore, the conducted analyses revealed that geopolitical, economic and administrative factors had major impact on the dynamics of the key indicators of the tourism sector in 2000-2015.

\section{References}

Report (2012). Eds. Kaurova O.V., Yumanova O.S., Chernikova L.I., Krivosheeva T.M., Zaytseva N.A., Larionova A.A., Maloletko A.N., Fedulin A.A., Kopylov Y.V. Vapnyarskaya O.I., Zaernyuk V.M., Zhuravleva N.V., Golikova O.M., Kugusheva A.N., \& Ogneva S.V.. Research report no. 47-K/2012 from 26.07.2012 (Agency for tourism of the Kaliningrad region). Research report "Formulation of framework for integrated tourism development in the Kaliningrad region for 2012-2018/2022, including measures for infrastructure development (restoration, building), the list of existing assets (or assets under reconstruction) with reference to specific tourist zones of the Kaliningrad region" [in Russian]

Anisiewicz, R., \& Palmowski, T. (2014). Small border traffic and crossborder tourism between Poland and the Kaliningrad oblast of the Russian Federation. Quaestiones Geographicae 33(2), 79- 88.

Aydarov, L.A., \& Lavrov, V.V. (2014). Formulation of development strategy for tourism and recreational system in the Kaliningrad region. Petersburg economic journal, no. 1, 83-90.

Derendyaeva, T.M., \& Muhina, G.A. (2013). Socio-legal issues of Russsia entering the WTO: through the example of tourism activity. Vestnik Kaliningradskogo filiala Sankt-Peterburgskogo universiteta MVD Rossii. no. 2 (32), 85-89.

Derkachenko, E.S., \& Filippov, U.U. (2014). The usage of modern teaching technologies in evaluation of cultural-historical space of the regions. Rossiyskie regiony: vzglyad v buduschee. no. 1 (1), 128-143

Dragileva, I. I. (2006). Crossborder cooperation in the development of tourism of the Southeast Baltic: autoref. of PhD dis. on Geography. Kaliningrad.

Fedorov, G.M., \& Korneevets, V.S. (2010). Transborder regions in the hierarchical system of regions: a systemic approach. Baltijskij region. No 2, 32-41.

Fedorov, G., Zverev, Y., \& Korneevets, V. (2011). Kaliningrad oblast of Russia in the transborder region Southeastern Baltic. Coastal Regions. No 19. Gdansk: University of Gdansk.

Fedrorova, T.A. (2015). Tourist framework in the Northwestern Federal District. Sovremennye problem nauki I obrazovaniya. no. 1-2, 305-320.

FL (2009) The Federal Law no. 123-FZ «On amendments to the article 17.2 of the Federal Law "On the principles of Tourist Activity in the Russian Federation" (28 June 2009) (in Russian)

Korneevets, V.S. (2010). International regionalization in the Baltic. Monograph. Saint-Petersburg: Saint Petersburg University Publ.

Korneevets, V.S., \& Kropinova, E.G. (2014). Forms of crossborder cooperation in the sphere of tourism within the CIS. Turizm $v$ evraziyskom prostranstve: realnosti I novye tendentsii: sbornik statey iz materialov Evraziyskogo nauchnogo foruma 04-05 dekabrya 2014 (pp 149-157). (Redaktsiya M.J. Spirinoy, A.A.Toropyginoj). Chast I. SPB: MIEP pri MPA EvrAeES.

Kropinova, E. G. (2014). The Project "Crossroads 2.0" in the development of a transborder tourism region in the Southeast Baltic. Pskovskiy regionalnyi zhurnal: Turizm i recreatia. No 17, 67-72.

Kropinova, E. G. (2010). International cooperation in the tourism sphere and the development of a crossborder tourism region in the Baltic. Vestnik Baltijskogo federalnogo universitita im.I.Kant. No. 1, 113-119.

Kropinova, E.G., \& Mitrofanova, A.V. (2011). Regional tourism cluster as a tourism and recreational system at a regional level. Regionalnye issledovaniya, 1(31), 40-46

Kropinova, E.G., Zaytseva, N.A., \& Moroz, M. (2015). 'Approaches to the Assessment of the contribution of Tourism into the regional surplus product: case of the Kaliningrad region'. Mediterranean Journal of Social Sciences. Vol.6, No.3, 2015. Rome, Italy. ISSN: 2029-2117.

Law (2006). Law of the Kaliningrad region dated 28 December 2006 no. 115 "On adoption of program of socio-economic development of the Kaliningrad region for 2007-2016" [in Russian].

Official website of the Ministry for tourism in the Kaliningrad region (2015). Official website of the Ministry of Tourism in the Kaliningrad region http://tourism.gov39.ru/ Accessed 20 July 2015.

On activities of collective accommodation facilities (2013). On activities of collective accommodation facilities (hotel-type) in the 
Kaliningrad region in 2012. Digest of statistics. Kaliningrad.

On activities of collective accommodation facilities (2014). On activities of collective accommodation facilities (hotel-type) in the Kaliningrad region in 2013. Digest of statistics. Kaliningrad.

On the activities of tourist companies (2011). On the activities of tourist companies of the Kaliningrad region in 2010. Digest of statistics. Kaliningrad.

On the activities of tourist companies (2012). On the activities of tourist companies of the Kaliningrad region in 2011. Digest of statistics. Kaliningrad.

On the activities of tourist companies (2013). On the activities of tourist companies of the Kaliningrad region in 2013. Digest of statistics. Kaliningrad.

On the activities of travel agencies of the Kaliningrad region in 2009 (2009). Digest of statistics. Kaliningrad.

Program "Tourism" (2013). Decree of the government of the Kaliningrad region dated 24.12.2013 N 993 "On state program of the Kaliningrad region "Tourism"' [in Russian].

Regions of Russia (2002). Regions of Russia: Socio-economic indicators. 2002. Moscow: Rosstat, 2002.

Regions of Russia (2006). Regions of Russia: Socio-economic indicators. Moscow: Rosstat. 2006.

Regions of Russia (2014). Regions of Russia: Socio-economic indicators. Moscow: Rosstat, 2014.

Rekunova, S.A. (2011). Current problems of regional tourism risk management in Russia. Obschestvennye nauki. no. 2, 141-143.

Report (2014). 2013 progress report on implementation of target program "The development of the Kaliningrad region as a tourist center for 2007-2014" (in Russian). Official website of the Ministry of Tourism in the Kaliningrad region. http://tourism.gov39. ru/activities/programma.php. Accessed 20 October 2014.

Report (2015). Report of the governor of the Kaliningrad region N.N. Tsukanov (in Russian). Official website of the Ministry of Tourism in the Kaliningrad region. http://tourism.gov39.ru/ Accessed 20 July 2015.

Semenova, L.V., Zaytseva, N.A., Kropinova, K.G., Dragileva, I.I., \& Gumenyuk, I.S. (2013). Cluster-based scientific-methodological approaches to elaboration of tourism development strategy in the Kaliningrad region: monograph - Kaliningrad: BFU of I. Kant Publ..

Spiriajevas, E. (2013). Development of international tourism in Lithuania: comparative analyses of regional aspects. Baltiyskiy region. no. $1,116-127$.

Strategy (2012). Decree of the government of the Kaliningrad region dated 02 August 2012 "On long-term strategy of social-economic development of the Kaliningrad region" [in Russian]. 